\title{
Cooperative Learning Model of P2RE type on Paragraph Writing Skills
}

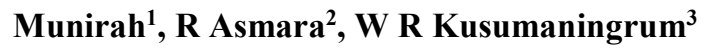 \\ 1 Department of Indonesian Language and Literature Education, Universitas Muhammadiyah \\ Makassar, Makassar, Indonesia \\ 2 Department of Indonesian Language and Literature Education, Universitas Tidar, Magelang, \\ Indonesia \\ 3 Department of English Education, Universitas Tidar, Magelang, Indonesia \\ E-mail: munirah@unismuh.ac.id; asmara@untidar.ac.id; \\ kusumaningrum@untidar.ac.id
}

\begin{abstract}
This study aims to prove the application of P2RE learning models to the ability to write paragraphs. The research design used in this study was a pre-experimental design (One-group Pretest-posttest Design). The population of this study was students of the fourth semester of Indonesian Language and Literature Education Study Program at Unismuh Makassar. Sampling is done by simple random sampling. The sample in this study, namely class IV A and B. Data collection techniques in this study were written test and observation techniques. The collected data was analyzed using descriptive statistics and inferential statistics using the t-test formula (paired sample t-test). The results of the study prove that paragraph writing skills after using P2RE (posttest) learning model are more effective than paragraph writing skills before using the cooperative learning model P2RE (Pretest) type after being analyzed using the t-test formula, the value of tcount $=3.662$ with $\mathrm{df} 25$, ttable $=2.060$. So $\mathrm{t}$ count $\geq \mathrm{t}$ table then the research hypothesis (H1) is accepted. This shows that the use of P2RE type cooperative learning model is effectively applied in paragraph writing skills in fourth-semester students of Indonesian Language and Literature Education Study Program in Universitas Muhammadiyah Makassar.
\end{abstract}

Keywords: Learning Model; P2re Type; Paragraph Writing Skills

\section{INTRODUCTION}

Writing learning conducted by lecturers still emphasizes the results and not yet in the writing process. Lecturers have not provided guidance and opportunities for students to try to improve their essays or writings, both regarding content and language, so that they can reach 
the level of perfection. Students are not treated as active and creative subjects because lecturers do not act as facilitators, motivators, and mentors in the learning process of writing. The theory of a student-centered approach seems to be completely ignored. As a result, most students lack in creative thinking. The low motivation of students is one of the main causes of writing. The cause of the low student learning outcomes is not solely due to the lack of ability, but also because of the use of methods and learning models that are less precise and not maximal. The model that is often used is the lecture method, direct learning model and assignment. The model used by lecturers do not direct students to study well. In writing learning, lecturers are expected to be able to develop appropriate learning models to improve student writing skills[1], [2]. Learning paragraph writing with practice orientation has not been an option since elementary school to college. It needs to be realized that to be skilled in writing; it is not enough to learn writing theory, the more decisive is the practice. This is obtained by the value of proficiency or skill which is the result of developing competencies into observable behaviors [3].

Munirah [4] stated that P2RE learning model was a cooperative learning model based on constructivism with the types of preparation, organizing, reflective, and evaluation. Preparation is inventory, or mental preparation students receive learning. Organizing is the process of ways and actions to organize learning. Reflective is a movement to monitor and give feedback and follow-up and appreciation in learning activities. Evaluation is a process of activities to measure the level of achievement of activities. The Stages of P2RE Learning Model:

a. Student Orientation in The Preparation Phase

- The lecturer checks the presence of students,

- The lecturer provides an introduction to students, motivate and open the horizons of thinking students about the subject matter in real life,

- Apperception by holding questions and answers on previous lessons, and

- The lecturer conveys the learning objectives.

b. $\quad$ Facilitate Students in The Organizing Phase

- The lecturer explains the learning material,

- The lecturer facilitates students in exploring the concept of learning by reviewing teaching materials,

- The lecturer gives assignments to students using MFIs,

- Students are grouped.

c. Guiding Students in The Reflective Phase

- The lecturer guides the implementation of student assignments in groups and facilitates discussion in groups,

- Students practice writing paragraphs,

- The lecturer guides the completion of student assignments,

- The lecturer asks one of the students to present their assignments, and other students listen,

- The lecturer gives comments and gives awards from the results of student assignments. 
- The lecturer tests and reconstructs the knowledge of writing paragraphs that are constructed in the reflective phase through class discussion.

- The lecturer evaluates the success of learning trough presentation of the results of work assignments and quizzes.

\section{METHODS}

The design used in this study was the pre-experimental design (one-group pretest-posttest design) [5]. Before conducting the learning process, students were given a pretest for knowledge of students' initial abilities. After that student were given posttest after following the learning process. Sampling was done by simple random sampling. Samples in this study namely class IV A (27 students) and IV B (25 students). This study took the data from students within the age range of 19-21 years old. The participants were both male and female university students. All of them were Indonesian with Indonesia/Makassar as their L1 and have been learning Indonesia at the Department of Indonesian Language and Literature Education for one year. Data collection techniques in this study were written test and observation techniques. The data collected were analyzed using descriptive statistics and inferential statistics using the t-test formula (paired sample t-test).

\section{RESULTS AND DISCUSSION}

P2RE cooperative learning model of paragraph writing skills in fourth-semester students of the University of Muhammadiyah Makassar is associated with mastery learning students who get an average score of 70 paragraphs and above with $85 \%$ completeness. The following is a completeness table for writing student paragraphs.

Table 1. Average Value of The Whole Class

\begin{tabular}{ccccc}
\hline No & Paragraph Type & \multicolumn{2}{c}{ Class Average Value } & \multirow{2}{*}{$\begin{array}{c}\text { Cumulative } \\
\text { Average } \\
\text { Value }\end{array}$} \\
\cline { 3 - 4 } & Class A & Class B & 76,99 \\
\hline 1 & Narrative & 76,37 & 74,66 & 81,25 \\
2 & Description & 82,33 & 78,58 & 80,75 \\
3 & Exposition & 79,83 & 81,67 & 70,47 \\
4 & Argumentation & 71,71 & 69,17 & \\
\hline
\end{tabular}

Based on table 1. The results of learning to write the paragraph above, the average value of the whole class is very varied from the four types of paragraphs taught. The narrative paragraph for class A gets an average value of 76.37 and class B 74.66 with a cumulative average value for the entire class in the narrative paragraph, which is 76.99 . The description paragraph for class A gets an average value of 82.33 and class B of 78.58, with a cumulative average value for the entire class in the description paragraph, namely, 81.25. The exposition paragraph for class A gets an average value of 79.83 and class B 81.67 with a cumulative average value for the entire class in the exposition paragraph, which is 80.75 . The arguments for class A get an average value of 71.71, and class B has an average value of 69.17, with a cumulative average value for the whole class in the argumentation paragraph, which is 70.47 . 
Table 2. Pretest and Posttest Results of Learning Writing Skills in Write Paragraphs

\begin{tabular}{ccc}
\hline Aspect Compared & Pretest & Posttest \\
\hline Mean (average value) & 2,39 & 2,84 \\
Lowes Value & 1,60 & 1,88 \\
Highest Value & 3,04 & 3,48 \\
Completeness with a value of 70 and & $34,61 \%$ & $84,61 \%$ \\
above & & \\
\hline
\end{tabular}

The results of inferential analysis using the SPSS application show that the value of $\mathrm{t}$ (the difference value of pretest and posttest is 3,662 with df 25). The value of $t$ table for df 25 is 2,060 means the value of $t$ count $>t$ table then the null hypothesis $(\mathrm{H} 0)$ is rejected and alternative hypothesis (H1 ) accepted so that there is a significant difference between the classes before using the cooperative learning model P2RE type (pretest) and after using the cooperative learning model P2RE type (posttest).

\section{CONCLUSION}

The overall student learning outcomes for narrative paragraph 76.99 , description paragraph 81.25 , exposition paragraph 80.75 , and argumentation paragraph 74.47 . The results of testing the effectiveness of the P2RE cooperative learning model indicate that the P2RE learning model meets the effectiveness criteria, namely the ability of lecturers to manage to learn by the P2RE type learning model categorized as good. The average percentage of lecturer activity in learning activities writing paragraphs according to the P2RE type model is more than $85 \%$, and the average percentage of student activity is more than $81 \%$. Paragraph writing skills in fourth-semester students before using the P2RE learning model (pretest) are in a low category. Skills in writing paragraphs of fourth-semester students after using P2RE (Posttest) learning model are in a good category. The number of students who obtained mastery scores $(\geq 2.66)$ was 52 people $(84.61 \%)$ from 56 students. Based on the results of the analysis the average value of the posttest was higher than the average value of the pretest. Through the t-test formula (paired sample $t$-test), the value of tcount $=3.662$ and $t$ table $=2.060$, means that the tcount $>$ ttable. This shows that there is a significant difference between pretest and posttest, meaning the research hypothesis is accepted.

\section{REFERENCES}

[1] G. . Tompkins and Hoskinson, Language Arts: Content and Teaching Strategies. New York: MacMillan Publishing Company, 1994.

[2] A. C. Alwasilah and A. S. Suzanna., Pokoknya Menulis. Bandung: Kiblat Buku Utama, 2008.

[3] H. Dervish, "Factors influencing job satisfaction of employees," Public Manag. Perspect., vol. 7, no. 1, pp. 123-126, 2011.

[4] Munirah, Pengembangan Menulis Paragraf. Yogyakarta: Deepublisch, 2015.

[5] J. W. Creswell, Research Design: Qualitative, Quantitative, and Mixed Methods Approaches. Los Angeles: Sage Publications, Inc, 2014. 